\title{
Etanercept okozta szubakut pajzsmirigygyulladás
}

\author{
Hella Zoltán dr. ${ }^{1}$ - Hodinka László dr. ${ }^{2}$ \\ Turbucz Piroska dr. ${ }^{1}$ - Kovács Gábor László dr. ${ }^{1}$ \\ ${ }^{1}$ Pest Megyei Flór Ferenc Kórház, I. Belgyógyászati Osztály, Kistarcsa \\ ${ }^{2}$ Országos Reumatológiai és Fizioterápiás Intézet, II. Reumatológiai Osztály, Budapest
}

\begin{abstract}
A 65 éves férfi beteg rheumatoid arthritis miatt napi 4 mg methylprednisolon-bázisterápia mellé öt éven át heti 50 mg etanerceptkezelésben részesült. A betegnél nyaki fájdalom, gyengeség, láz, nyelészavar jelentkezett, amihez normális vérkép mellett gyorsult vörösvértest-süllyedés $(88 \mathrm{~mm} / \mathrm{h})$, emelkedett CRP $(49,3 \mathrm{mg} / \mathrm{l})$ és hyperthyreosis (TSH 0,006 mIU/1, fT4 27,22 pmol/1, fT3 5,61 pmol/l) társultak. A normális tartományban lévő thyreoidea-peroxidáz elleni antitest és TSH-receptor elleni antitest értékei az autoimmun eredetet kizárták. Az ultrahangvizsgálat fokálisan csökkent echószerkezetú és vascularisatiójú pajzsmirigyet jelzett, amelyek alapján az etanerceptkezeléssel összefüggésbe hozható destruktív/szubakut thyreoiditisnek megfelelő betegséget diagnosztizáltunk. Az etanercept elhagyásával, valamint öt napig napi $16 \mathrm{mg}$, majd hét napig napi $8 \mathrm{mg}$, majd ezt követően napi $4 \mathrm{mg}$ methylprednisolon adása mellett a beteg klinikai tünetei átmeneti javulás után romlottak, így a methylprednisolon-kezelést megismételtük (öt napig napi $16 \mathrm{mg}$, majd két hónapig napi $8 \mathrm{mg}$ ); ezután a pajzsmirigyfunkció és a gyulladásos állapot rendeződött. Esetismertetésünkben szeretnénk felhívni a figyelmet az etanercept egyik - Magyarországon elsőként leírt - esetleges mellékhatására, ami a pajzsmirigyfunkció időszakos ellenőrzését teszi szükségessé.

Orv Hetil. 2017; 158(39): 1550-1554.
\end{abstract}

Kulcsszavak: destruktív thyreoiditis, etanercept, methylprednisolon-kezelés

\section{Etanercept-induced subacute thyroiditis}

\section{Case report and literature review}

65 years old male patient received $4 \mathrm{mg}$ /day methylprednisolone baseline therapy and $50 \mathrm{mg} /$ week etanercept treatment for 5 years due to rheumatoid arthritis. The patient experienced pain in neck, and developed weakness, fever and dysphagia. He had normal blood count but accelerated erythrocyte sedimentation rate ( $88 \mathrm{~mm} /$ hour $)$, elevated CRP (49.3 mg/l) and hyperthyroidism (TSH $0.006 \mathrm{mIU} / \mathrm{l}$, fT4 $27.22 \mathrm{pmol} / \mathrm{l}$, fT3 $5.61 \mathrm{pmol} / \mathrm{l})$. The autoimmune origin could be excluded because of normal values of antibodies against thyreoidea peroxidase and TSH receptor. The ultrasound investigation showed focal hypoechogenic structure and low vascularisation. Based on the laboratory and ultrasound results as well as clinical signs etanercept related subacute thyroiditis was supposed. As part of the treatment we interrupted the etanercept treatment and gave $16 \mathrm{mg}$ methylprednisolone for 5 days, then $8 \mathrm{mg}$ for 7 days, after that the patient received the daily $4 \mathrm{mg}$ of methylprednisolone as baseline therapy. After rapid improvement the symptoms got worse again so we repeated the administration of methylprednisolone treatment with a higher dose ( $16 \mathrm{mg} /$ day for 5 days then $8 \mathrm{mg}$ /day for two months). Thyroid functions and the inflammatory markers got normalized. We conclude the necessity of monitoring the thyroid function during etanercept treatment thus avoiding this rare but serious side effect.

Keywords: destructive thyroiditis, etanercept, methylprednisolone treatment

Hella Z, Hodinka L, Turbucz P., Kovács GL. [Etanercept-induced subacute thyroiditis. Case report and literature review]. Orv Hetil. 2017; 158(39): 1550-1554.

(Beérkezett: 2017. április 24.; elfogadva: 2017. július 10.)

\section{Rövidítések}

$\mathrm{CRP}=$ C-reaktív protein, $\mathrm{fT} 3=$ szabad trijód-tironin, $\mathrm{fT} 4=$ szabad tiroxin, $\mathrm{MTP}=$ methylprednisolon, $\mathrm{RA}=$ rheumatoid arthritis, SAT = szubakut thyreoiditis, TNF = tumornekrózisfaktor, TNFR = tumornekrózisfaktor-receptor, TSH = thyreoideastimuláló hormon 
Esetismertetésünkben a világon széles körben ismert és az autoimmun ízületi gyulladások egyes típusaiban jelenleg is sikeresen alkalmazott gyulladáscsökkentő szer, az etanercept egy ritka, Magyarországon eddig még nem ismert mellékhatását tárgyaljuk. A rheumatoid arthritis kezelésében a világon körülbelül 15 éve alkalmazott TNF-gátló kezelés és kis dózisú szteroidkezelés jelen esetalanyunknál öt évig okozott remissziót, amikor lázzal járó türhetetlen nyaki fájdalom és nyomásérzékenység miatt sürgősségi betegellátó osztályunkon megjelent. A fizikális vizsgálattal a felső légúti gyulladás kizárható volt, mellkas-röntgenvizsgálat alapján az alsó légúti infekció lehetőségét elvetették, a TSH-érték alapján felmerült thyreotoxicosis okán helyezték osztályunkra további kivizsgálás és kezelés céljából. A pajzsmirigy-autoantitestek negatívak voltak. A pajzsmirigy-ultrahangvizsgálat, illetve emelkedett gyulladásos paraméterek alapján az akut szuppuratív thyreoiditis diagnózisát elvetettük, ugyanakkor a labor és ultrahangkép felvetette a szubakut thyreoiditis lehetőségét. A két alkalommal alkalmazott magasabb dózisú szteroidkezelés alapján észlelt gyors állapotjavulás - egyéb ok hiányában - az etanercept okozta szubakut thyreoiditist erósítette meg. Jelen tanulmányunkban az etanercept ezen oki szerepét vizsgáljuk meg.

\section{Esetismertetés}

A 65 éves férfi beteg kórelőzményéből perforált nyombélfekély miatti mútét, ischaemiás szívbetegség, magasvérnyomás-betegség emelendő ki. A betegnél osztályunkra történő felvételét megelőzően két évvel tachyarrhythmia absoluta miatt amiodaron bevezetése történt. Az amiodaronkezelés elkezdése előtt a beteg euthyreoid volt (TSH: 0,62 $\mathrm{mIU} / 1$, normáltartomány: 0,27-4,2; Synlab Kft.). Az amiodarontelítéstől számított négy hónap múlva amiodaron indukálta hyperthyreosis miatt a gyógyszer leállítása történt, illetve ettől fogva Basedow-típusú amiodaron indukálta hyperthyreosis gyanúja miatt thiamazolkezelése indult. Két hónap thiamazolkezelés mellett a beteg euthyreoiddá vált (TSH: 0,87 mIU/1, normáltartomány: 0,4-4,0; Centrum-Lab Kft.), a thiamazol leállításától számított harmadik hónapban is euthyreosisra utaltak a laboratóriumi értékek (TSH: 0,47 mIU/1, normáltartomány: 0,4-4,0; Centrum-Lab Kft.). Ezt követően a betegnél perzisztens pitvarfibrilláció miatt rádiófrekvenciás vena pulmonalis izolációt végeztek, amely mellett tartós sinusrhythmust lehetett elérni.

A beteg 57 éves korától kezdve rheumatoid arthritis (RA) miatt rendszeres gondozás alatt állt. Az RA miatt hosszú ideje alkalmazott napi $4 \mathrm{mg}$ methylprednisolon (MTP) mellett a felvételét megelőző mintegy öt éven át heti $50 \mathrm{mg}$ etanercept $\left(\right.$ Enbrel $\left.^{\circledR}\right)$-kezelésben is részesült, amely mellett a rheumatoid arthritise úgy klinikailag, mind laborparamétereit tekintve egyensúlyban volt.

A beteg felvételére öt napja fennálló nyaki fájdalom, gyengeség, láz, illetve nyelési nehezítettség miatt került sor. A beteg tüneteit felső légúti vírusfertőzés nem előzte meg. Felvétele előtt három héttel panaszmentes állapotban történt laborokban enyhe fokú hyperthyreosisszindróma mutatkozott (TSH: $0,32 \mathrm{mIU} / 1$, normáltartomány 0,4-4,0, illetve FT4 15,47 pmol/1, normáltartomány 7,75-15,21 pmol/1), amely mellett süllyedése normális tartományban volt $(20 \mathrm{~mm} / \mathrm{h}$, normáltartomány 1-20; Centrum-Lab Kft.), CRP-értéke enyhén emelkedett volt (11,88; normális tartomány: $<5)$, ez utóbbi a sokízületi gyulladás aktivitásának megfelelt. A felvételi klinikai tünetekhez jellegzetes laboreltérések is társultak: az érdemi kórosat nem mutató vérkép mellett gyorsult vörösvértest-süllyedés $(88 \mathrm{~mm} / \mathrm{h}$, normáltartomány 1-20), mérsékelten emelkedett CRP (49,3 mg/1, normáltartomány $0-5$ ), valamint hyperthyreosisnak megfelelő laboreltérések: TSH 0,006 mIU/1 (normáltartomány 0,27-4,2), fT4 27,22 pmol/1 (normáltartomány 12-22), fT3 5,61 pmol/1 (normáltartomány 3,1-6,8; Synlab Kft.) voltak láthatóak. A laborvizsgálatok az autoimmun pajzsmirigygyulladást nem támasztották alá: a thyreoidea-peroxidáz elleni antitest (anti-TPO) $8 \mathrm{IU} / \mathrm{ml}$ (normáltartomány <35) és a TSHreceptor elleni antitest (TRAK) 0,36 IU/1 volt (normáltartomány <1,5; Synlab Kft.). Az ultrahangvizsgálat csökkent echószerkezetű és csökkent vascularisatiójú pajzsmirigyet jelzett, az akut bakteriális thyreoiditist kizárta (1. és 2. ábra).

A klinikai tünetek és a laboreredmények alapján a rheumatoid arthritis miatt bevezetett etanerceptkezeléssel összefüggésbe hozható szubakut/destruktív thyreoiditisnek megfelelő betegséget diagnosztizáltunk. Az etanercept elhagyásával, valamint öt napig $16 \mathrm{mg}$, majd egy hétig $8 \mathrm{mg}$, végül a báziskezelésként egyébként is alkalmazott napi $4 \mathrm{mg}$ MTP adása mellett a beteg klinikai tünetei jelentősen javultak, de a láz, nyaki fájdalom, emelkedett CRP egy hónap múlva ismét visszatértek, így a betegnél ismételten öt napig $16 \mathrm{mg}$, majd 21 napig 8 mg MTP-terápiát alkalmaztunk. A klinikai tünetek javulását követően a beteg napi 4 mg fenntartó adagú MTPkezelésben részesült, és a fennálló rheumatoid arthritist figyelembe véve jelenleg is ezt a kezelést alkalmazzuk.

A pajzsmirigyfunkció normalizálódása egy hónap után következett be, és a hyperthyreosis a későbbiekben sem tért vissza. A vörösvértest-süllyedés és CRP-értékek teljes normalizálódására a továbbra is fennálló RA alapbetegség miatt nem lehetett számítani. A laborparaméterek és klinikai tünetek változása a kezelés függvényében az 1 . táblázatban olvasható. A klinikai tünetek megjelenését követően fél évvel végzett pajzsmirigy-szcintigráfia továbbra is csökkent technéciumfelvételt $(0,49 \%)$ jelzett homogén izotópeloszlás mellett, ami a pajzsmirigyet destruáló folyamat fennállását igazolta.

Két évvel a betegség kialakulása után a betegnél nyaki fájdalom, illetve hyper- vagy hypothyreosisra utaló klinikai tünetek nem állnak fenn. Továbbiakban a kontrollpajzsmirigyultrahangvizsgálaton új elváltozásként leírásra került körülírt echószegény pajzsmirigy-elváltozások 

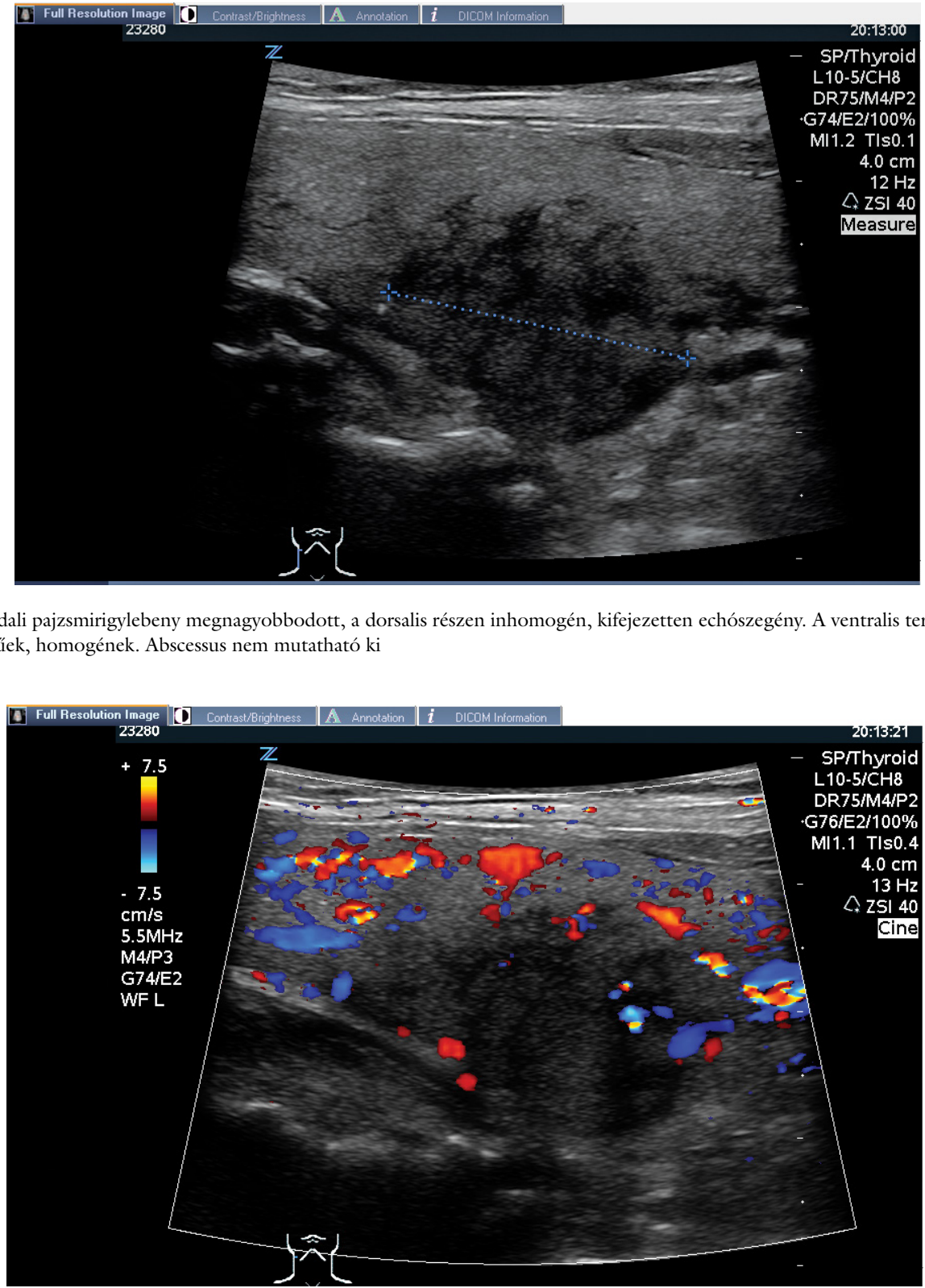

2. ábra

\begin{abstract}
Az ultrahangképen a beteg pajzsmirigyének jobb lebenyében fokális gyulladásos terület látható, ahol a kép centrumában inhomogén, echószegény, rosszul határolt képlet erezettsége a környező struktúrákhoz képest egyértelmúen csökkent. Az erezettség hiánya alátámasztja a célterületen zajló destruktív gyulladásos folyamat jelenlétét. A beteg nyomon követése során ez az elváltozás érdemben nem módosult, erezettsége, mérete később is
\end{abstract} hasonló maradt

nyomon követését és időszakosan a pajzsmirigyfunkció ellenőrzését tervezzük.

A betegnél az etanercept elhagyását követően három hónappal az alapbetegségként fennálló RA tünetei fokozódtak, ezért adalimumab (Humira ${ }^{\circledR}$ ) -kezelés indult (40 mg sc. injekció kéthetente), ami mellett hyperthyreosisra utaló klinikai jeleket nem találtunk. A beteg pajzsmirigyfunkcióját ezt követően háromhavonta ellenőrizzük, a mai napig euthyreoid.

\section{Megbeszélés}

A szubakut thyreoiditist (SAT) a szakirodalomban első leírója után de Quervain-thyreoiditisnek, a szövettani jellemzői alapján szubakut granulomatosus nonszuppuratív thyreoiditisnek, illetve óriássejtes thyreoiditisnek is nevezik. Ez a pajzsmirigygyulladás egy ritka, önmagát többnyire limitáló, spontán gyógyhajlamot is mutató betegség, ami többnyire felső légúti vírusos infekció után alakul ki. Ezen vírusfertőzések lehetnek mumpsz, Epstein-Barr-vírus, Coxsackie A- és B-vírus, echovírus, cytomegalovirus, adenovírus, rhinovirus, influenzavírus, parvovírus B19, rubeola, kanyarófertőzések [1, 2]. Kutatások és klinikai esetek azt mutatták, hogy a vírusinfekción kívül egyéb hajlamosító tényező is szükséges ahhoz, hogy a betegség kialakuljon. Ilyen prediszponáló tényezőnek tartják a HLA-B35-ös asszociációt is, mivel a 
1. táblázat |A klinikai tünetek, kezelés és laborértékek változása az első négy hónapban (zárójelben a normáltartományok)

\begin{tabular}{|c|c|c|c|c|c|c|}
\hline Időpont & 2013.11.21 & 2014.09 .11 & 2014.10 .06 & 2014.11. 05. & 2014.11 .10$. & 2015.01 .13$. \\
\hline Klinikai tünet & Panaszmentes & $\begin{array}{l}\text { Nyaki fájdalom nincs, } \\
\text { láz nincs, panaszmen- } \\
\text { tes }\end{array}$ & $\begin{array}{l}\text { Erős nyaki fájdalom, } \\
\text { láz, hyperthyreosisra } \\
\text { utaló klinikai jelek }\end{array}$ & $\begin{array}{l}\text { Nyaki fájdalom, láz, } \\
\text { nincs hyperthyreo- } \\
\text { sisra utaló jel }\end{array}$ & $\begin{array}{l}\text { Enyhe nyaki } \\
\text { fájdalom, nincs láz, } \\
\text { nincs hyperthyreosis }\end{array}$ & $\begin{array}{l}\text { Nincs nyaki } \\
\text { fájdalom, nincs } \\
\text { láz, nincs } \\
\text { hyperthyreosis }\end{array}$ \\
\hline Süllyedés $(\mathrm{mm} / \mathrm{h})$ & NA & $20(0-20)$ & $88(0-20)$ & $42(0-20)$ & $12(0-20)$ & $16(0-20)$ \\
\hline CRP & $4,4(<5)$ & $11,88(<5)$ & $49,3(<5)$ & $44(<5)$ & $7,8(<5)$ & $6,52(<5)$ \\
\hline TRAK (IU/1) & NA & NA & $0,38(<1,5)$ & NA & NA & NA \\
\hline $\operatorname{aTPO}(\mathrm{IU} / \mathrm{ml})$ & NA & NA & $8(<35)$ & NA & NA & NA \\
\hline $\mathrm{TSH}(\mathrm{mIU} / \mathrm{l})$ & $0,87(0,4-4,0)$ & $0,32(0,4-4,0)$ & $0,006(0,27-4,2)$ & $0,01(0,27-4,2)$ & $0,02(0,27-4,2)$ & $2,20(0,27-4,2)$ \\
\hline $\mathrm{fT} 4(\mathrm{pmol} / \mathrm{l})$ & NA & $15,47(7,75-15,21)$ & $27,22(12-22)$ & NA & $14,91(12-22)$ & $14,72(12-22)$ \\
\hline fT3 $(\mathrm{pmol} / \mathrm{l})$ & NA & NA & $5,61(3,1-6,8)$ & NA & $4,79(3,1-6,8)$ & $4,72(3,1-6,8)$ \\
\hline Terápia & Nem igényelt & Nem igényelt & $\begin{array}{l}\text { Etanercept } \\
\text { elhagyása, MTP öt } \\
\text { napig } 16 \mathrm{mg} \text {, majd } \\
\text { MTP hét napig } 8 \\
\text { mg, majd MTP } \\
\text { naponta } 4 \mathrm{mg} \\
\text { tartósan }\end{array}$ & $\begin{array}{l}\text { MTP öt napig } 16 \\
\text { mg }\end{array}$ & $\begin{array}{l}\text { MTP naponta } 8 \\
\text { mg tartósan }\end{array}$ & $\begin{array}{l}\text { MTP naponta } 4 \\
\text { mg tartósan }\end{array}$ \\
\hline
\end{tabular}

betegek körülbelül kétharmada hordozza ezt a humán leukocyta-antigént $[3,4]$.

A betegség patogenezisében kulcsszerepe van a gyulladás következtében kialakuló sejtszétesésnek, aminek következtében a pajzsmirigy sejtjeiből pajzsmirigyhormon, tiroxin szabadul fel. A betegség képes spontán remisszióra, de a nyaki fájdalom, láz és a hyperthyreosis klasszikus klinikai tünetei mielőbbi javítása érdekében szükség lehet gyulladáscsökkentő terápia alkalmazására, ami jellemzően nem szteroid gyulladáscsökkentő gyógyszereket (NSAID), illetve szteroidkezelést (prednisolon, methylprednisolon) foglalja magában.

A tumornekrózis-faktor (TNF) a rheumatoid arthritis során kialakuló gyulladásos folyamatban meghatározó szerepú citokin. Az etanercept kompetitíve gátolja a TNF sejtfelszíni receptorokon való kötődését, és ezáltal gátolja a TNF biológiai aktivitását [5]. Az etanercept egy fúziós fehérje, amelyet rekombináns DNS-technológiával állítottak elő úgy, hogy a TNF-receptor az $\mathrm{IgG}_{1}$ ellenanyag Fc részével olvad egybe. Az etanercept és a pajzsmirigygyulladások közti kapcsolat pontos patomechanizmusa nem ismert. Nagy valószínúséggel a $T_{1}$ és $\mathrm{Th}_{2}$ lymphocyták vér és nyirok, valamint szövetek közötti mozgásának szabályozott folyamata, azaz az úgynevezett „homing” sérül, ugyanis a lymphocyták vándorlásában, majd a letelepedésében kulcsfontosságú citokinek és a receptorainak a kapcsolódása módosul, ami gyulladáshoz vezet. A gyulladás folyamán az extracelluláris mátrixban található adhéziós molekulák, lymphocytás és endothelsejtek kapcsolata károsodik, ami szövetszétesést eredményezhet.

A TNF-gátló kezelés és autoimmun thyreoiditis kapcsolatáról van leírás a nemzetközi irodalomban [6]. Az etanercept és pajzsmirigybetegségek vonatkozásában több eset is közlésre került, de nem SAT, hanem szubakut/fájdalmatlan lymphocytás thyreoiditis formájában. Ilyenkor emelkedett thyreoglobulinellenes autoantitest szint volt észlelhető a TSH emelkedésével, klinikai vagy szubklinikus hypothyreosissal [7].

Allanore és mtsai már 2001-ben közölték egy 37 éves nó esetét, aki szeropozitív RA miatt etanerceptkezelésben részesült. Ebben az esetben az etanercept bevezetése után fél évvel alakult ki szubklinikus hyperthyreosis. A pajzsmirigyellenes antitestek negativitása mellett a pajzsmirigyultrahang és -szcintigráfia is negatív volt, így a SAT diagnózisát elvetették. A szteroid dózisának emelésére nem volt szükség, az etanercept szedését nem állították le, a hyperthyreosis propranolol adása mellett egy hónap leforgása alatt rendeződött [8].

Cañas és mtsai közölték az első olyan 32 éves férfi esetét, akinél az RA miatt alkalmazott etanerceptkezelés összefüggésbe volt hozható SAT kialakulásával. A közölt esetben az etanercept elhagyásával, illetve szteroidkezelés mellett a klinikai tünetek megszüntek, de egy évvel később pajzsmirigy-alulmúködés alakult ki [9]. Yasuji által közölt esetismertetésben egy 24 éves, juvenilis rheumatoid arthritis miatt öt éven keresztül heti $25 \mathrm{mg}$ etanerceptkezelésben részesülő nőbetegnél jelentkező nyaki fájdalom és érzékenység, magas láz, nyelési nehezítettség, gyorsult süllyedés, magas CRP, valamint pajzsmirigybetegségekre specifikus autoantitestek hiánya mellett jelentkező hyperthyreosisra utaló laboreltérések hátterében SAT-ot diagnosztizáltak. Az ultrahangvizsgálat echószegény pajzsmirigyet jelzett; számos vírusmarker-vizsgálat negatív eredménnyel zárult. Az etanerceptkezelés felfüggesztésével az RA miatt alkalmazott bázisprednisolon adagjának átmeneti emelésével a beteg panaszai megszűntek. Három hónappal a kiindulási tü- 
netek után pajzsmirigy-alulmúködést detektáltak, ami miatt pajzsmirigyhormon-szubsztitúciós kezelés bevezetésére volt szükség [2].

Esetismertetésünkben szeretnénk felhívni a figyelmet az etanercept egyik fontos - Magyarországon elsőként leírt - esetleges mellékhatására, ami a pajzsmirigyet érintheti. Jelen esetben a beteg valószínúleg egyéb hajlamosító tényezôvel is rendelkezhetett, tekintve, hogy korábban már átesett amiodaron okozta pajzsmirigygyulladáson, ami sokkal gyakrabban jelentkező pajzsmirigybetegség és nagy valószínűséggel nem csak az amiodaronban található nagy mennyiségű jód okozta folyamatra vezethető vissza.

A betegnél a SAT gyanúja esetén tireoglobulinszintet kellett volna meghatározni, amely SAT esetén mérhetetlenül magas. Ugyanakkor a vélt diagnózis időpontjában elvégzett pajzsmirigy-szcintigráfia és/vagy vékonytü-aspirációs biopszia egyértelművé tette volna a diagnózist. Az előbbi alacsony technéciumfelvételt mutatott volna, az utóbbi a jellegzetes többmagvú óriássejteket, granulomákat, sérült folliculusokat. A hyperthyreosis észlelésétől számított fél év múlva készült szcintigráfia viszont megerősítette a destruktív thyreoiditist, jóllehet, a diagnózistól számított pár hónap múlva a betegek 90\%-ának a pajzsmirigymúködése meggyógyul. A relapsussal járó thyreoiditis hosszabb gyógyulási folyamatot jelenthet. $\mathrm{Az}$ eddigi irodalmi közlések alapján az etanercepthez köthető pajzsmirigy-diszfunkciók a kezelés alatt bármikor, akár több évvel annak elkezdését követően is kialakulhatnak, így a kezelés alatt a pajzsmirigymúködés időszakos ellenőrzése feltétlen indokolt.

Szubakut thyreoiditis esetén irodalmi adatok alapján még megpróbálható szolúbilis TNF-receptor adása (pegsunercept), illetve TNF-ellenes monoklonális antitestek elkezdése is lehetséges (infliximab, adalimumab, certolizumab, golimubab) [10]. A beteg az adalimumabkezelés mellett klinikailag és laborparamétereit tekintve is euthyreoid, a TSH értékét háromhavonta ellenőrizzük, hiszen adalimumab mellett is leírásra került már a szubakut thyreoiditis, arthritis psoriatica kezelése kapcsán [11].

Mivel a beteg folyamatos kis dózisú MTP-kezelésben részesült, kérdés, hogy szteroid-bázisterápia hiányában, időben hamarabb, lefolyásában súlyosabb SAT jelentkezett volna-e. A beteg osztályunkra történő felvétele előtt a laborok már panaszt nem okozó hyperthyreosisra utaltak. A thyreoidea-peroxidáz autoantitest negativitása kizárta az akut autoimmun thyreoiditis lehetőségét. Mivel a nyaki fájdalom hiánya nem zárja ki a kezdődő szubakut thyreoiditis lehetőségét, véleményünk szerint a laborok előrevetítették a későbbiekben panaszt okozó betegséget. A szubakut thyreoiditis kezelésében azért nem törekedtünk a $16 \mathrm{mg}$ feletti és a hónapokig tartó MTP adására, mivel az évek óta tartó szteroidkezelés szövődményeit nem akartuk súlyosbítani. A $4 \mathrm{mg}$ MTP mellett relapsussal járó betegség miatt mégis arra kényszerültünk, hogy még egy hónapig a bázisszteroid adagjánál magasabb dózissal kezeljük a beteget.
A betegnél utólag, a SAT gyógyulása utáni euthyreoid állapotában esetlegesen detektálható, lezajlott vírusfertőzésre utaló ellenanyagok jelenléte csak pozitivitás esetén okozna fejtörést, negativitás esetén megerősítené az általunk feltételezett diagnózist. Kórházunkban lehetőség lett volna a diagnózis időpontjában Epstein-Barr-vírus, Coxsackie A- és B-vírus, echovírus, cytomegalovirus, adenovírus, rhinovirus, influenzavírus, parvovírus B19, rubeola-IgM mérésére.

Anyagi támogatás: A közlemény megírása anyagi támogatásban nem részesült.

Szerzôi munkamegosztás: A dolgozat megírásában a szerzők egyenlő arányban vettek részt. A cikk végső változatát valamennyi szerző elolvasta és jóváhagyta.

Érdekeltségek: A szerzőknek nincsenek érdekeltségeik.

\section{Irodalom}

[1] Desailloud R, Hober D. Viruses and thyroiditis: an update. Virology J. 2009; 6: 5 .

[2] Yasuji I. Subacute thyroiditis in a patient with juvenile idiopathic arthritis undergoing etanercept treatment: a case report and review of the literature. Mod Rheumatol. 2013; 23: 397-400.

[3] Zein EF, Karaa SE, Megarbane A. Familial occurrence of painful subacute thyroiditis associated with human leukocyte antigenB35. Presse Med. 2007; 36: 808-809.

[4] Nyulassy S, Hnilica P, Buc M, et al. Subacute (de Quervain's) thyroiditis: association with HLA-Bw35 antigen and abnormalities of the complement system, immunoglobulins and other serum proteins. J Clin Endocrinol Metab. 1977; 45: 270-274.

[5] Instructions for use Enbrel. (Enbrel alkalmazási előírás.) http:// www.ema.europa.eu/docs/hu_HU/document_library/EPAR__Product_Information/human/000262/WC500027361.pdf [Hungarian]

[6] Coles AJ, Wing M, Smith S, et al. Pulsed monoclonal antibody treatment and autoimmune thyroid disease in multiple sclerosis. Lancet 1999; 354: 1691-1695.

[7] Andrés E, Limbach FX, Goichot B, et al. Silent thyroiditis associated with etanercept in rheumatoid arthritis. Ann Rheum Dis. 2002; 61: 565 .

[8] Allanore Y, Bremont C, Kahan A, et al. Transient hyperthyroidism in a patient with rheumatoid arthritis treated by etanercept. Clin Exp Rheumatol. 2001; 19: 356-357.

[9] Cañas CA, Tobón GJ, Arango LG, et al. Developing of granulomatous thyroiditis during etanercept therapy. Clin Rheumatol. 2009; 28(Suppl 1): S17-S19.

[10] Stevenson M, Archer R, Tosh J, et al. Adalimumab, etanercept, infliximab, certolizumab pegol, golimumab, tocilizumab and abatacept for the treatment of rheumatoid arthritis not previously treated with disease-modifying antirheumatic drugs and after the failure of conventional disease-modifying antirheumatic drugs only: systematic review and economic evaluation. Health Technol Assess. 2016; 20: 1-610.

[11] Senlis M, Ottaviani S, Gardette A, et al. Subacute thyroiditis in psoriatic arthritis treated by adalimumab. Joint Bone Spine 2016 Nov 4. DOI: 10.1016/j.jbspin.2016.09.015. [Epub ahead of print]

(Hella Zoltán dr., Kistarcsa, Semmelweis tér 1., 2143 e-mail: zoltan.hella.dr@gmail.com) 